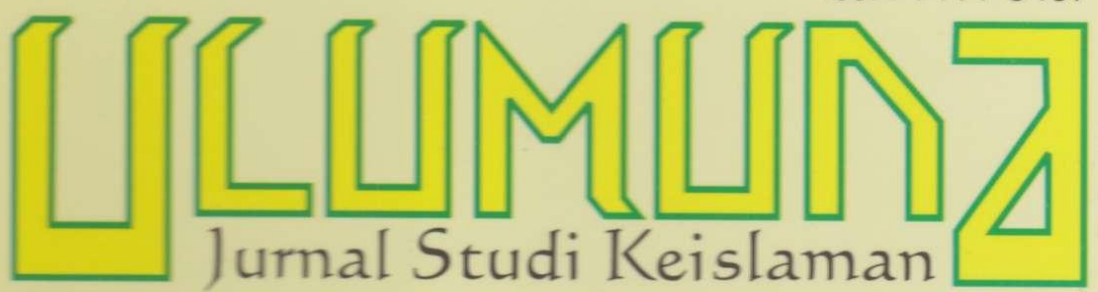

Volume 16 • Nomor 2• Desember 2012

Terakreditası B; SK Dirjen Dikti Kemdikbud Nomor: 56/DIKTI/Kep/2012, Tanggal 24 Juli 2012

REORIENTASI KAJIAN TEOLOGI ISLAM: IKHTIAR KONTRIBUTIF ATASI PROBLEM KEKINIAN Muhammad Rusli

PERGOLAKAN TEOLOGI SYIAH-SUNNI: MEMBEDAH POTENSI INTEGRASI DAN DISINTEGRASI

Slamet Mulyono MEnimbang KontorVERSI PEMAKNAAN KONSEP AHL AL-KITĀB DALAM AL-QUR'AN Zulyadain ECOTHEOLOGY:

TEOLOGI KONSTRUKTIF ATASI KRISIS LINGKUNGAN Abdul Quddus AKU DALAM TUHAN: IMPLIKASI TEOLOGI PROSES PADA ERA KONTEMPORER Suhermanto la'far PERgulatan TEOLOGI SALAFI DALAM MAINSTREAM KEBERAGAMAAN MASYARAKAT SASAK Faizah STUDI KOMPARATIF KONSEP KETUHANAN ISLAM DAN AGAMA ADAM PADA KOMUNITAS SAMIN Mohammad Rosyid KEGALAUAN IDENTITAS:

Dilema Hubungan Komunitas Muslim dan Hindu di BalI Siti Raudhatul Jannah 



\section{DAFTAR ISI}

\section{Pedoman Transliterasi}

223-244 • Muhammad Rusli,

"Reorientasi Kajian Teologi Islam:

Ikhtiar Kontributif Atasi Problem Kekinian"

245-278 • Slamet Mulyono,

"Pergolakan Teologi Syiah-Sunni:

Membedah Potensi Integrasi dan Disintegrasi"

279-310 Zulyadain,

"Menimbang Kontorversi Pemaknaan

Konsep Ahl Al-Kitāb Dalam Al-Qur'an"

311-346 • Abdul Quddus,

"Ecotheology:

Teologi Konstruktif Atasi Krisis Lingkungan"

347-374 • Suhermanto Ja'far,

"Aku dalam Tuhan:

Implikasi Teologi Proses pada Era Kontemporer"

375-402 • Faizah,

"Pergulatan Teologi Salafi

dalam Mainstream Keberagamaan Masyarakat Sasak"

403-442• Mohammad Rosyid,

"Studi Komparatif Konsep Ketuhanan Islam

dan Agama Adam pada Komunitas Samin"

443-464 • Siti Raudhatul Jannah,

"Kegalauan Identitas: Dilema Hubungan

Komunitas Muslim dan Hindu di Bali"

\section{INDEKS}

APENDIKS 


\section{PEDOMAN TRANSLITERASI}
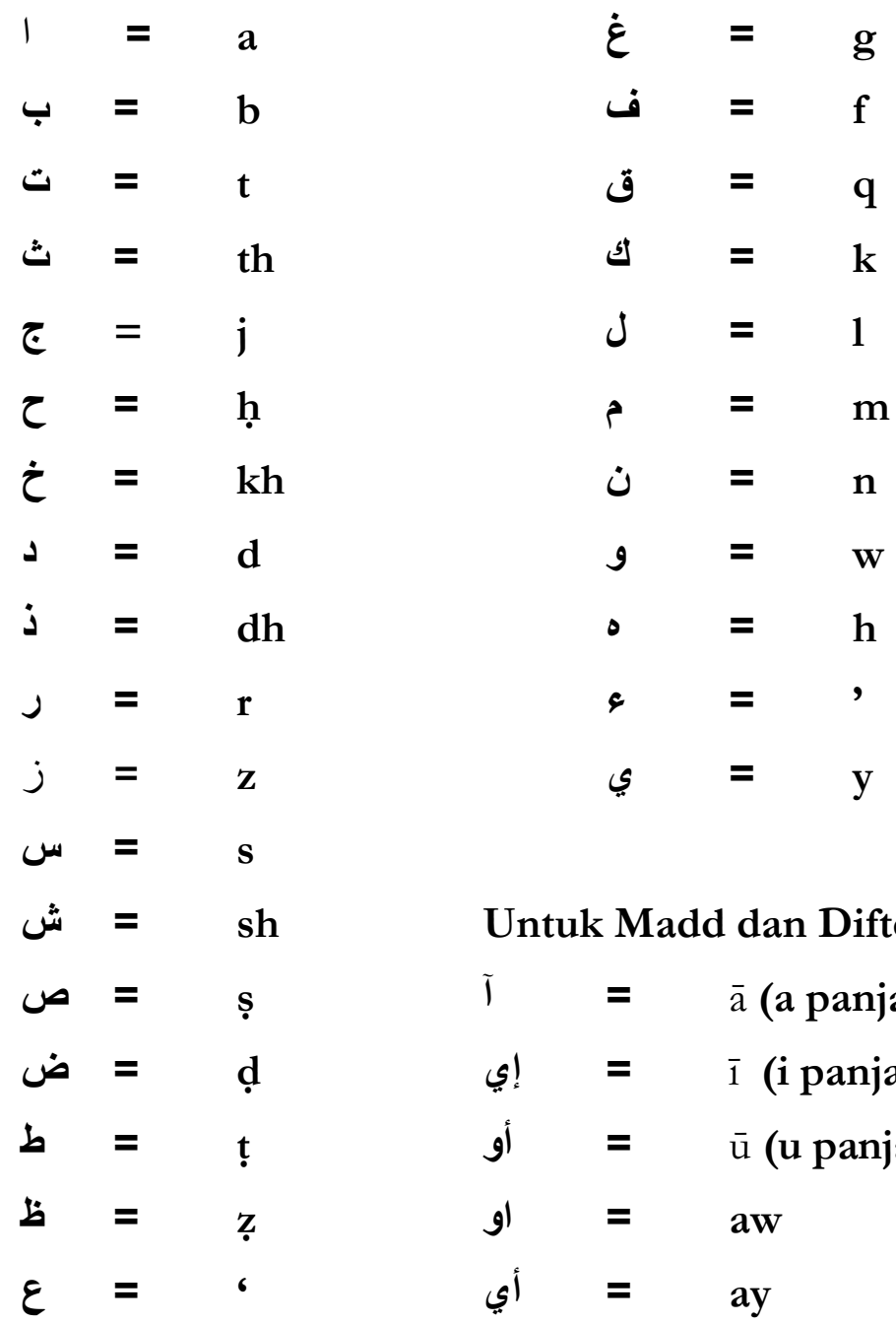

= $\quad y$

Contoh penulisan dengan transliterasi:

اعوذ بالله من الشيطان الرجيم (a'üdhu bi al-Lāh min al-shaytān al-rajìm);

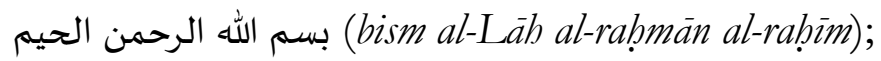

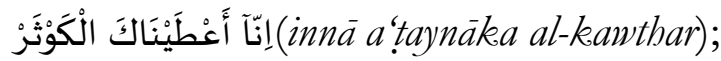

فَصََلِّ لِرَبِكَ وَانْحَرْ (faşalli lirabbika wanhar); صباح الخير (sabāh al-khayr). 


\title{
ECOTHEOLOGY ISLAM: TEOLOGI KONSTRUKTIF ATASI KRISIS LINGKUNGAN
}

\author{
Abdul Quddus \\ (Jurusan PAI Fakultas Tarbiyah IAIN Mataram \\ Email: nadasultan09@yahoo.com)
}

Abstract: The earth inhabited by buman now is facing global environmental crisis. To respond to and tackle the crisis, a new awareness to explore the principles of religion has emerged today, which was then called ecotheology, an integral environmental insight based on ethical-theological as well as ethical-anthropological dimensions. This paper is aimed at, on the one hand, exposing principles of Islamic ecotheology that are able to be guiding principles in managing the nature, and on the other hand, comparing them with the principles of modern environmental ethics of the environmentalist/ eco-thinkers. The author argues that there are three principles of Islamic ecotheology that are relevant as the basis of ethical management of nature now days, namely the principle of tawhid (unity of all creation), the principle of ämanah-khalifah (trustworthiness-moral leadership), and äkhirah (responsibility).

Abstrak: Bumi yang dibuni manusia sekarang ini tengah dilanda krisis lingkungan yang besifat global. Untuk merespons krisis itu, dewasa ini telah muncul kesadaran baru dalam menanggulangi krisis itu dengan menggali prinsip-prinsip agama, yang kemudian disebut ecotheology, yaitu wawasan lingkungan yang integral dan berdimensi etis-theologis dan etisantropologis. Tulisan ini bertujuan untuk, di satu sisi, memapar prinsipprinsip ecotheology Islam yang dapat dijadikan sebagai guiding principles dalam pengelolaan alam, dan di sisi lain, mengomparasikan prinsip-prinsip itu dengan etika lingkungan modern dari para environmentalist/eco-thinker. Penulis berpendapat babwa ada tiga prinsip ecotheologi Islam yang relevan sebagai basis etis pengelolaan alam dewasa ini, yaitu prinsip tawhīd (kesatuan selurub makhluk), prinsip amānah-khalīfah (kejujuran-kepemimpinan), dan ākhirah (tanggung jawab).

Keywords: ecotheology, krisis lingkungan, tawhīd, amānah-khalīfah, àkhirah. 
MUNCULNYA berbagai permasalahan lingkungan baik lokal, regional maupun global dewasa ini semakin mengkhawatirkan. Perubahan iklim, akibat dari global warming menyebabkan bumi tidak lagi seimbang yang berdampak pada tidak dapat diprediksikannya sesuatu musim. Di belahan bumi yang lain curah hujan begitu tinggi hingga mengakibatkan banjir dan erosi sementara di belahan lainnya terjadi kekeringan yang berkepanjangan.

Kerusakan sumber daya alam (tanah, air, udara), deforestasi, degradasi hutan, dan kebakaran hutan pun makin sering terjadi, musnahnya berbagai spesies hayati, naiknya permukaan air laut dan tenggelamnya beberapa pulau, serta merebaknya berbagai jenis penyakit adalah beberapa bentuk masalah lingkungan yang menuntut perlunya solusi dengan segera. Dampak negatif lingkungan tersebut secara dominan dan signifikan bersumber dan berakar pada perilaku eksploitatif dan konsumtif manusia yang berparadigma antroposentris dengan menempatkan manusia sebagai centre of the universe.

Wacana mengenai krisis lingkungan di kalangan akademisi mulai mengemuka pada tahun 1960-an dengan munculnya beberapa karya populer seperti karya Rahel Carson yang berjudul The Silent Spring pada Tahun 1962, Lynn White dengan judul The Historical Roots of Our Ecological Crisis pada majalah Science, Maret 1967, dan Tragedy of Commons oleh Garett Hardins Tahun $1968 .{ }^{1}$

Dalam menganalisa penyebab krisis lingkungan global tersebut, Fritjof Capra ${ }^{2}$ berpendapat bahwa krisis tersebut merupakan akibat dari worldview dan keserakahan manusia terhadap alam, baik keserakahan karena kemiskinan, kebodohan atau keserakahan untuk menghimpun kekayaan yang banyak. Demikian pula tidak difungsikannya perangkat nilai

${ }^{1}$ Kirkpatrick Sale, The Green Revolution: The American Environmental Movement, 1962-1992, ter. Natheos Naller, Revolusi Hijau: Sebuab Tinjauan Historis-Kritis Gerakan Lingkungan Hidup di Amerika Serikat (Jakarta: Yayasan Obor Indonesia, 1996).

${ }^{2}$ Fritjof Capra peraih Ph.D dari Universitas Vienna, telah banyak melakukan riset fisika energi tinggi di berbagai universitas baik Eropa maupun Amerika, di samping sejumlah tulisan riset yang bersifat teknis. Ia juga banyak menulis dan mengajar tentang implikasi filosofis sains modern. 
transendental dalam diri manusia untuk dijadikan sebagai acuan moral dalam hidup. Secara lebih khusus ia mengatakan bahwa musibah Bumi terjadi akibat pengembangan ilmu pengetahuan dan teknologi yang minus wawasan spiritual. Lebih lanjut Capra mengutip R.D. Laing menyatakan, “... Kita telah menghancurkan dunia ini secara teori sebelum kita menghancurkannya dalam praktik...". ${ }^{3}$ E.F. Schumacher menyatakan bahwa masalah krisis lingkungan ini sangat terkait dengan krisis kemanusiaan, dengan moralitas sosial serta krisis orientasi manusia terhadap Tuhan. ${ }^{4}$ Pernyataan yang hampir sama dikemukakan oleh wakil presiden Amerika AlGore, ia menyatakan:

semakin dalam saya menggali akar krisis lingkungan yang melanda dunia, semakin mantap keyakinan saya bahwa krisis ini tidak lain adalah manifestasi nyata dari krisis spiritual kita. ${ }^{5}$

Hal yang menggembirakan menurut Capra adalah munculnya kesadaran Barat akan hal tersebut dengan berbagai gerakan ekologi, feminism, dan small is beautiful dalam bidang perekonomian. $^{6}$

\section{Fakta Krisis Lingkungan Global dan Lokal}

Secara global, krisis ekologi minimal tergambar dalam tiga bentuk kerusakan lingkungan yaitu, global warming, menipisnya lapisan ozon, dan hujan asam (acid rain). Berikut akan dijelaskan salah satu dari tiga bentuk kerusakan lingkungan yang paling mengkhawatirkan yaitu global warming.

Global warming adalah proses peningkatan suhu rata-rata atmosfer, laut dan daratan bumi. Suhu rata-rata global pada

${ }^{3}$ Frithjof Capra, The Web of Life (London: Harper Collins, 1996), dan Fritjof Capra, The Turning Point: Science, Society and The Rising Culture (London: Flamingo, 1984). Lihat juga The Tao of Physic; An Explorationof the parallels Between Modern Physic and Eastern Mysticism (London: Flamingo, 1982), 21.

${ }^{4}$ E. F. Schumacher, A Guide for The Perplexed (New York: Harper Colophon Books, 1978), 139.

${ }^{5}$ Albert Gore, Jr, Earth in the Balance: Ecology and the Human Spirit (New York: Houghton Mifflin, 1992), 269. Buku ini telah diterjemahkan oleh Hira Jhamtani, Bumi Dalam Keseimbangan; Ekologi dan Semangat Manusia (Jakarta: Yayasan Obor Indonesia, 1994).

${ }^{6}$ Capra, The Turning, 26. 
permukaan bumi telah meningkat $0.74 \pm 0.18{ }^{\circ} \mathrm{C}(1.33 \pm 0.32$ $\left.{ }^{\circ} \mathrm{F}\right)$ selama seratus tahun terakhir. Intergovernmental Panel on Climate Change (IPCC) ${ }^{7}$ menyimpulkan bahwa, sebagian besar peningkatan suhu rata-rata global sejak pertengahan abad ke-20 kemungkinan besar disebabkan oleh meningkatnya konsentrasi gas-gas rumah kaca akibat aktivitas manusia melalui efek rumah kaca. Kesimpulan dasar ini telah dikemukakan oleh setidaknya 30 badan ilmiah dan akademik, termasuk semua akademisi sains nasional dari negara-negara G8. ${ }^{8}$

Meningkatnya suhu global diperkirakan akan menyebabkan perubahan-perubahan yang lain seperti naiknya permukaan air laut, meningkatnya intensitas fenomena cuaca yang ekstrem, serta perubahan jumlah dan pola presipitasi. Akibat-akibat pemanasan global yang lain adalah terpengaruhnya hasil pertanian, hilangnya gletser, dan punahnya berbagai jenis hewan. ${ }^{9}$

Perubahan iklim adalah proses panjang hasil konsumsi energi berlebih dan tidak berkelanjutan oleh negara-negara industri. Sejak dilangsungkannya revolusi industri, lingkungan global menderita pencemaran udara yang berdampak besar pada perubahan situasi bumi. Penggunaan teknologi dalam rangka eksploitasi alam memainkan peran yang esensial dalam mempengaruhi situasi tersebut. Salah satu akibatnya adalah peningkatan emisi gas rumah kaca (GRK) secara tidak alami di atmosfer bumi, ${ }^{10}$ kemudian berdampak pada memanasnya suhu

7IPCC atau Panel Antar Pemerintah Tentang Perubahan Iklim, terbentuk di bawah inisiatif gabungan Organisasi Metereologi Dunia (World Meteorological Organization) dan Program Lingkungan PBB (United Nation Environment Programme) pada Tahun 1988.

${ }^{8}$ Mengenai seluk beluk global warming, selanjutnya lihat Hadi S. Ali Kodra, Bumi Makin Panas Banjir Makin Luas; Menyibak Tragedi Hutan, (Bandung: Yayasan Nuansa Cendikia, 2004), 21.

'WWF dalam laporannya, Habitat at Risk 2002, menyebutkan bahwa jika emisi karbon meningkat 2X lipat 100 tahun mendatang, maka diperkirakan $80 \%$ spesies tanaman dan binatang akan punah. Hadi S. Ali Kodra, "Kapasitas Pengelolaan SDA dan Lingkungan Hidup", Diktat Seminar Kajian Islam Komprehensif (Jakarta: Pascasarjana UIN Jakarta, 2007), 45.

${ }^{10}$ Urutan tiga besar dunia sebagai penyumbang emisi gas rumah kaca adalah China, Amerika dan Indonesia. Lihat Agus P. Sari (ed), Indonesia and Climate Change: an Assessment of the Environmental Impacts of Climate Change 
bumi yang sangat berbahaya bagi mayoritas populasi di dunia dan bagi ekosistem. Perubahan iklim ini merupakan isu yang terkait dengan masalah pembangunan, hak asasi manusia, dan keadilan yang sedang berkembang di tengah krisis ekologi yang dihadapi masyarakat dunia.

Pemanasan global adalah rangkaian tahap dari terjadinya perubahan iklim global (climate change). Proses terjadinya pemanasan global diawali dengan fenomena efek rumah kaca (greenhouse effect). Di bumi, efek rumah kaca dihasikan oleh gasgas tertentu yang jumlahnya sedikit di atmosfer. Selain itu, es, titik-titik air dan partikel-partikel kecil di atmosfer juga menangkap panas. Gerald Foley menyebutkan peran GRK telah dibahas oleh para ilmuan selama lebih dari 150 tahun. ${ }^{11}$

Pemanasan global tidak terjadi dalam jangka waktu singkat, tapi berangsur-angsur. Namun demikian, dampaknya sudah mulai terasa saat ini. Dalam laporan yang dikeluarkan IPCC Tahun 2001, disimpulkan bahwa:

Temperatur udara global telah meningkat $0,6^{\circ} \mathrm{C}\left(1^{\circ} \mathrm{Fahrenheit}\right)$ sejak 1861. IPCC setuju bahwa pemanasan tersebut terutama disebabkan oleh aktifitas manusia yang menambah gas-gas rumah kaca ke atmosfer. IPCC memprediksi peningkatan temperatur rata-rata global akan meningkat $1.1^{\circ} \mathrm{C}$ hingga $6.4^{\circ} \mathrm{C}\left(2.0\right.$ hingga $\left.11.5^{\circ} \mathrm{F}\right)$ antara tahun 1990 dan $2100 .{ }^{12}$

Meskipun konsentrasi gas di atmosfer tidak bertambah lagi sejak tahun 2010, iklim tetap terus menghangat selama periode tertentu akibat emisi yang telah dilepaskan sebelumnya. Akibatnya, akan terjadi perubahan iklim secara dramatis. Walaupun sebenarnya peristiwa perubahan iklim ini telah terjadi beberapa kali sepanjang sejarah Bumi, manusia akan menghadapi masalah ini dengan resiko populasi yang sangat besar. ${ }^{13}$

Across a Range of Sectors Including Health, Food Security and Employment (DFID \& Bank Dunia, Juni 2007). Lihat juga Walhi, Kenali Perubahan Iklim, Resiko dan Masalahnya (Jakarta: Penerbit Walhi, 2007), 41.

${ }^{11}$ Gerald Foley, Pemanasan Global; Siapakah yang Merasakan Panas? (Jakarta: Yayasan Obor Indonesia, 1993), 2.

12IPCC

Third

Assessment

Report,

http://www.grida.no/climate/ipcc_tar/

13James Hansen, "Climatic Change: Understanding Global Warming, One World: The Health \& Survival of the Human Species in the 21st Century", www.mail-archive.com/Pemanasan_Global. 
Penelitian yang dilakukan oleh berbagai lembaga dunia dan laporan yang disampaikan, khususnya terkait dengan perubahan iklim, seperti: UNFCCC, IPCCC, UNEP, UNCED, WCP, demikian halnya organisasi-organisasi pemerhati lingkungan seperti WWF, Greenpeace, WALHI, menunjukkan bahwa suhu bumi telah meningkat secara drastis.

Indonesia tercatat sebagai sebagai penghancur hutan tercepat dengan laju penghancuran hutan rata-rata 1,871 juta hektar pertahun (2 persen) dari hutan yang tersisa. Bahkan WALHI (Wahana Lingkungan Hidup Indonesia) mencatat angka tersebut pernah mencapai 3,4 juta hektar pertahun. Kerugian akibat illegal loging mencapai 40-65 triliun setiap tahunnya. Tahun 2003, laju kerusakan hutan menurun menjadi 3,2 juta hektar dan Tahun 2005 berkisar 2,4 juta hektar. Konsekuensi dari eksploitasi dan penebangan hutan tersebut mengakibatkan 673 bencana terjadi di Indonesia sejak tahun 1998-2004 dan lebih dari $65 \%$ diantaranya adalah dampak dari pengelolaan hutan yang tidak benar sehingga menimbulkan banjir, longsor dan kebakaran hutan.

Wilayah pantai dan lautan Indonesia juga terus mengalami kerusakan dan degradasi. Lautan Indonesia merupakan salah satu dari sedikit hotspot terumbu karang $^{14}$ di dunia yang mengalami kerusakan. Data dari Bank Dunia menunjukkan bahwa:

Saat ini sekitar 41\% terumbu karang dalam keadaan rusak parah, 29\% rusak, 25\% lumayan baik, dan hanya 5\% yang masih dalam keadaan alami. Begitu juga menyangkut kawasan mangrove atau hutan bakau. Sekitar 50\% hutan bakau di Sulawesi telah hilang (sebagian diantaranya berubah menjadi kawasan tambak udang). Beberapa kawasan juga mengalami pencemaran. Ini terjadi di kawasan-kawasan yang sibuk dengan kegiatan pelayaran (Selat Malaka), atau perairan yang bersinggungan dengan kota-kota besar, seperti perairan teluk Jakarta dan Surabaya. Wilayah laut Indonesia juga rentan dengan illegal fishing. Kegiatan ini dilakukan oleh lebih dari 10 negara asing sejak 15 tahun

${ }^{14}$ Indonesia termasuk salah satu dari 6 negara yang merupakan kawasan Coral Triangel Iniative (CTI) yang biasa disingkat CT6. Negara lainnya adalah Malaysia, Filiphina, Kepulauan Solomon, Timur Leste, dan Papua Nugini). 
terakhir dan telah mengurangi 30-50 \% total potensi perikanan tangkap nasional tiap tahun. ${ }^{15}$

Di sektor lain, siklus terjadinya kebakaran hutan dunia terjadi terus menerus. Indonesia adalah negara yang memiliki kawasan hutan alam asli (intact ancient forests) terbesar di Asia, namun kawasan tersebut mengalami laju kehancuran lebih cepat -sekitar 1,19 juta hektar per tahun- ${ }^{16}$ dari wilayah lain di dunia, sehingga dianggap sebagai masalah global karena merupakan penyumbang besar terhadap perubahan iklim dunia. Menurut Hapsoro, Juru Kampanye Greenpeace Asia Tenggara, kerusakan tersebut adalah akibat dari eksploitasi manusia dan penghancurannya terhadap hutan gambut secara besar-besaran. Kementerian Kehutanan Indonesia menekankan bahwa hutan merupakan rumah bagi berbagai kehidupan, sehingga kelangsungan hidup berbagai spesies bergantung kepada kelestarian hutan untuk masa yang panjang. ${ }^{17}$

\section{Ecotheology Sebagai Sebuah Paradigma}

Ecotheology adalah bentuk teologi konstruktif yang menjelaskan hubungan agama dan alam (interrelationships of religion and nature), khususnya dalam hal lingkungan. Dasar pemahaman ecotheology adalah kesadaran bahwa krisis lingkungan tidak semata-mata masalah yang bersifat sekuler, tetapi juga problem keagamaan yang akut karena berawal dari pemahaman agama yang keliru tentang kehidupan dan lingkungan. Melalui ecotheology, dilakukan tafsir ulang terhadap pemahamanpemahaman agama di tengah masyarakat, utamanya mengenai posisi manusia, relasi dan tanggung jawabnya berkaitan dengan bumi ini.

Pengertian "teologi" dalam konteks ini adalah cara "menghadirkan" dalam setiap aspek kegiatan manusia. Dalam

${ }^{15}$ Alieansi Manado, Menggusur Nelayan Meneggelamkan keadilan Iklim,; Sisi gelap Bahaya WOC dan CTI (Alieansi Manado, 2009), 2.

${ }^{16}$ Valerina Daniel, COP 13 (Jakarta: Kementerian Lingkungan Hidup, 2007), 2.

${ }^{17}$ Ministry of Forestry UN Climate Change Conference 2007, Sustainable Forest Development as Reflection of Faith and Piety (Perum Perhutani, 2007), 2. 
bahasa lain, teologi dapat dimaknai sebagai konsep berpikir dan bertindak yang dihubungkan dengan "Yang Gaib" yang menciptakan sekaligus mengatur manusia dan alam. Jadi, terdapat tiga pusat perhatian (komponen) bahasan yakni Tuhan, manusia, dan alam, yang ketiganya mempunyai kesatuan hubungan fungsi dan kedudukan. Jadi, teologi hubungan antara manusia dan alam dengan Tuhan adalah "konsep berpikir dan bertindak tentang lingkungan hidup yang mengintegrasikan aspek fisik (alam termasuk hewan dan tumbuhan), manusia dan Tuhan". ${ }^{18}$

Relasi antara tiga kutub, yaitu Tuhan, alam dan manusia harus berjalan selaras, seimbang dan harmonis. Penghilangan salah satu kutub tersebut akan menyebabkan kepincangan. Penghilangan kutub Tuhan akan menyebabkan sekulerisme yang mengeksploitasi alam dan berujung pada krisis lingkungan. Penghilangan kutub alam, akan menjadikan manusia miskin pengetahuan dan miskin peradaban.

Istilah Ecotheologi mulai tersebar setelah Lynn White ${ }^{19}$, Toynbee ${ }^{20}$, dan Daisatsu Ikeda yang berkesimpulan bahwa worldview antroposentris agama-agama monoteis-lah yang menyebabkan terjadinya krisis ekologi. Perintah untuk mendominasi alam mengakibatkan munculnya pendekatan terhadap alam yang bersifat instrumental, bukan menghormati dan inilah kemudian yang menjadi ladang subur bagi berkembangnya sains dan teknologi yang destruktif terhadap lingkungan. Untuk mengatasinya menurut White, harus meninggalkan monoteisme dan berpaling menuju panteisme ${ }^{21}$

${ }^{18}$ Mujiyono, Teologi Lingkungan Islam, Disertasi (SPS UIN Syarif Hidayatullah Jakarta, 2005), 5.

${ }^{19}$ Lynn White, Jr., The Historical Roots of Our Ecological Crisis, Science 155 (10 Maret 1967), 1203-7.

${ }^{20}$ Arnold Toynbee, The Relegious Background of the Present Environmental Crisis, dalam Ecology and Religion in History, ed. David and Eileen Spring (New York: Harper and Row, 1974), 147. Ia mengatakan: The remedy (of envirinmental cricis) lies in reverting from the weltanschaunng of monotheism to the weltanschaunng of pantheism, which is older and was once more universal.

${ }^{21}$ Panteisme secara sederhana sering didefinisilkan sebagai keidentikan Tuhan dengan alam. Persoalan ontologis hubungan antara Tuhan dan alam 
dan tradisi-tradisi agama timur untuk membangun kosmologi yang berwawasan spiritual. ${ }^{22}$

Thesis Lynn White tidak berhenti pada kritiknya terhadap Yahudi dan Kristen, selanjutnya ia menyebut Marxisme, Islam, dan ideologi-ideologi modernis pencerahan seperti Pragmatisme Deweyian dan konsep perkembangan ekonomi Amerika sebagai bentuk bid'ah (bentuk baru) Yudeo-Kristen.

...that Marxism, like Islam, is a Judeo-Christian heresy. We continue today to live, as we have lived for about 1700 years, very largely in a context of Christian axioms. ${ }^{23}$

Kritik-kritik tentang ajaran monoteistik juga dikemukakan oleh G. Tyler Miller yang menyerukan pengakhiran terhadap ideologi Yahudi, Kristen, dan filsafat Yunani yang non-ekologis mengenai dominasi, penguasaan, dan kendali manusia atas bumi, (karena menurutnya manusialah yang merupakan bagian dari bumi dan bumi bukanlah milik manusia). ${ }^{24}$

Keith Thomas memberikan kritik dan memosisikan Islam sama dengan agama Yahudi dan Kristen dalam hal ketidakramahannya terhadap lingkungan. Dalam berbagai ayat al-Qur'an menyebutkan bahwa alam dan segala isinya diciptakan

adalah persoalan klasik yang sudah lama dibicarakan oleh para teolog, filusuf dan sufi. Istilah panteis pertama kali digunakan oleh John Toland (Deis asal Irlandia) dalam karyanya Sonicianism Truly Stated, 1750. Sedangkan kata penteisme pertamakali digunakan oleh lawan Toland, Fay (1709). Selanjutnya lihat Alasdair Maclntyre, "pantheism' The Encyclopedia of Philosophy, Ed. Paul Edwards, vol.8 (New York: The Macmillan Company \& The Free Press, 1967), 5 dan 34. Pembahasan Panteisme dan Panenteisme yang hubungannya dengan dunia tasawuf dilakukan oleh Kautsar Azhari Noer. Kautsar menjelaskan Tipe-tipe Panteisme serta perbedaan dan persamaannya dengan konsep tasawuf $W$ ahdatul $W$ ujud Ibn Arabi. Selanjutnya lihat Kautsar Azhari Noer, Ibn 'Arabi; Wabdatul Wujud dalam Perdebatan (Jakarta; Paramadina, 1995), 159.

22White, The Historical, 24. Selanjutnya lihat W. Chang, Jiwa Kosmis Frnasiskus dari Asisi, (Ende: Nusa Idah, 1989), 5.

${ }^{23}$ White, The Historical, 85.

${ }^{24} \mathrm{G}$. Tyler Miller, Reflenish The Earth: A Primer in Human Ecology, (Belmnt. Calif: Wadsworth, 1972), 53. Khusus mengenai kritik terhadap Islam, lihat juga Ziauddin Sardar, Islamic Futures (New York: Mensell Publishing Limited, 1985), 218. 
untuk manusia, sehingga manusia mempunyai otoritas yang tidak terbatas (unlimited) dan hak-hak istimewa (privilege) terhadap pemanfaatan alam. Manusia bebas menggunakan dan mengeksploitasi alam untuk kepentingan dan kesenangan mereka. Spesies tumbuhan dan hewan dianggap tidak mempunyai hak sehingga layak untuk dilukai dan disakiti. ${ }^{25}$

Thesis White di atas mendapat penolakan dan kritik hampir di seluruh wacana dan perdebatan mengenai akar krisis lingkungan terutama dari komunitas religius. Namun harus diakui bahwa sebenarnya kritik White terhadap monoteisme tersebut mempunyai peran signifikan dalam upaya merumuskan dan menafsir ulang konsep teologi dan etika monoteisme agar lebih ramah terhadap lingkungan. Dalam konteks inilah, membangun sebuah teologi yang berbasis kesadaran dan kearifan eskologis-yang disebut sebagai ecotheology-menjadi sebuah keharusan dan kebutuhan.

\section{Perdebatan Seputar Akar Krisis Lingkungan}

John Passmore (Filusuf dan Sejarawan Amerika) mendedah karakteristik dan perkembangan dari pandangan-pandangan kodrat manusia Barat yang dominan. Ia memberi ciri pandangan tersebut dengan tiga karakteristik, yaitu: pertama manusia sebagai penguasa zalim; kedua, konsep penjagaan (stewardship); ketiga, sikap-sikap yang menyatakan bahwa mansuia mengembangkan dan menyempurnakan alam. ${ }^{26}$ Di samping itu, Passmore juga menguraikan mengapa hingga saat ini, relasi antara manusia dan alam masih menyisakan banyak masalah. Passmore membagi permasalahan yang tengah dihadapi manusia di berbagai belahan dunia dewasa ini ke dalam 4 kategori, yaitu: Pollution (Polusi), The Depletion of natural resource (penipisan sumber daya alam), The

${ }^{25}$ Selanjutnya lihat Keith Thomas, Man and The Natural World; Changing Attitude in England (London: Allen Lane, 1983), 21. Lihat juga Ibrahim Ozdemir, "Toward an Understanding of Environmental Ethics from Qur'anic Perspective", Researh Seminar "Religion and Ecology" (Yogyakarta: CRCS, August, 9-13 2005), 14.

${ }^{26}$ Selanjutnjya lihat John Passmore, Man's Responsibility for Nature: Ecological Problem and Western Tradition (New York; Scribner's, 1974), 73. 
Destruction of species (musnahnya berbagai jenis spesies akibat ulah manusia), dan over population (populasi umat manusia yang semakin banyak). ${ }^{27}$

Keempat hal tersebut di atas merupakan problema yang nyata, yang saat ini menjadi kekhawatiran bersama para ecothinker dan aktifis lingkungan hidup diseluruh dunia. Masalah tersebut berakar pada pola pikir yang menomorsatukan manusia di atas alam; karena itu bagi manusia, alam adalah sesuatu yang harus ditaklukkan. Pola pikir ini dapat kita temukan sepanjang tradisi Barat (western) berkembang. Tradisi dimana manusia kemudian menjadi zalim (despot) terhadap alamnya, karena pendasaran metafisis yang keliru.

Secara umum ada beberapa faktor yang melatarbelakangi timbulnya masalah-masalah lingkungan, yakni teknologi, populasi penduduk dunia, ekonomi, dan worldview. ${ }^{28}$ Berikut akan dijelaskan secara detail berbagai faktor yang melatarbelakangi terjadinya krisis lingkungan.

\section{Careless Teknologi}

Barry Commoner dalam buku "the Closing Circle" melihat bahwa teknologi merupakan sumber terjadinya masalah-masalah lingkungan. Terjadinya revolusi di bidang ilmu pengetahuan alam (misalnya fisika dan kimia), yang terjadi selama lima puluh tahun terakhir, telah mendorong perubahan-perubahan besar di bidang teknologi. Selanjutnya hasil-hasil teknologi itu diterapkan dalam sektor industri, pertanian, transportasi dan komunikasi. Berdasarkan pengamatan di Amerika Serikat, Commoner menunjukkan terjadinya permasalahan lingkungan; pencemaran lingkungan meningkat setelah Perang Dunia II (Dua). Otto Soemarwoto mengutip Goldsmith menjelaskan bahwa sifat teknologi telah banyak merusak lingkungan. Teknologi telah mengganti biosfer yang sangat halus dan terkait pada pemeliharaan stabilitas jangka panjang, yaitu kelangsungan hidup

${ }^{27}$ Ibid., 32. Khususnya dalam part one "The Tradition".

${ }^{28}$ Sebagai bahan perbandingan, lihat Otto Soemarwoto, "Masalah Lingkungan Nasional dan Global; Sebuah Ikikhtisar", Makalah dalam seminar Sehari tentang Agama Dan Lingkungan Hidup (Jakarta: Juli 1991). 
menjadi teknosfer yang relatif kasar dan bertujuan untuk memenuhi kebutuhan jangka pendek manusia. ${ }^{29}$

\section{Ledakan Pertumbuban Penduduk}

Kesenjangan dua kutub pertumbuhan yakni population penduduk dan kebutuhan selalu menjadi perbincangan para ilmuan dan negarawan di berbagai belahan dunia. Manusia sebagai subsitem dari ekositem pada hakekatnya di-supplay secara kontinyu oleh subsistem lainnya. Dari korelasi ini akan menimbulkan masalah lingkungan apabila terjadi ketidakharmonisan. Jika manusia sebagai subsistem mengalami tingkat massa (populasi) yang melampui supply maka dalam waktu tertentu kebutuhan pokok manusia yang bersumber dari ekosistemnya (natural resources) akan mengalami kemerosotan. Pernyataan ini diperkuat dengan teori Malthus yang mengatakan bahwa jarak tingkat pertumbuhan penduduk akan semakin meloncat jauh ke atas, yang dapat digambarkan dengan deret ukur. Sedangkan tingkat pertumbuhan kebutuhan penduduk mempunyai batas-batas pertumbuhan tertentu yang hanya meningkat secara deret hitung. Hal inilah yang dapat mengakibatkan kegoncangan di bidang pengadaan pangan manusia. ${ }^{30}$

Paul R. Ehrlich menekankan, bahwa pertumbuhan penduduk dan peningkatan kekayaan memberikan sumbangan penting terhadap penurunan kualitas lingkungan hidup. Ia menolak pandangan Commoner bahwa pengembangan dan penerapan teknologi baru ke dalam berbagai sektor yang dimulai pada tahun 1940 sebagai penyebab terjadinya masalah-masalah lingkungan. ${ }^{31}$

Ehrlich berpendapat bahwa jauh sebelum teknologi maju dikembangkan seperti masa modern ini, bumi telah mengalami

${ }^{29}$ Selanjutmya lihat Otto Soemarwoto, Analisis Mengenai Dampak Lingkungan (Yogyakarta: UGM Press, 2007), 6.

${ }^{30}$ NHT Siahaan, Lingkungan dan Ekologi Pembangunan (Jakarta: Erlangga, 2004), h. 102.

${ }^{31}$ Tentang hasil penelitiannya baca selanjutnya Paul R. Ehrlich, Population Bomb (New York: Ballatine Books, tt). 
bencana lingkungan. Mereka menunjukan beberapa contoh, yakni terjadinya gurun pasir di lembah Sungai Euphrate dan Sungai Tigris, yang pada zaman sebelum Masehi terkenal sebagai kawasan subur. Terjadinya kerusakan pada kawasan yang semula subur itu disebabkan oleh sistem irigasi yang gagal dan pembukaan lahan yang terus menerus akibat pertumbuhan penduduk sehingga semakin luas lahan pertanian berdasarkan sistem irigasi. Di kawasan-kawasan yang curah hujannya rendah, kegagalan pengelolaan irigasi seringkali menimbulkan masalahmasalah lingkungan hidup yang serius, yaitu terjadinya masalah salinisasi (peningkatan kandungan garam di tanah). Kawasankawasan yang curah hujannya rendah mengalami tingkat penguapan yang tinggi, sehingga telah menyebabkan kekeringan irigasi. Kekeringan air irigasi sangat potensial menyebabkan terjadinya gurun pasir. Terjadinya kegagalan irigasi tidak saja dihadapi oleh negara-negara berkembang, tetapi juga negaranegara maju.

Dalam hubungannya dengan perkembangan populasi manusia yang terus berkembang pesat, Friedman mengistilahkan hal tersebut seperti karakteristik virus, terus berkembang biak menutupi bumi. Tak heran ada yang mengatakan bahwa ancaman masa depan bagi umat manusia bukanlah ledakan bom teroris, melainkan ledakan demografis. Bagi Friedman, kehancuran bumi terjadi tatkala crowded (demografi) bertemu dengan flat (globalisasi). Di titik pertemuan itu, yang menjadi korban dari keduanya tak lain adalah mother nature yang menjadi tempat bersandar manusia.

Lester E. Brown (ahli pertanian Departemen Pertanian USA) berhasil mendeskripsikan 22 (dua puluh dua) masalah terkait dengan laju pertumbuhan penduduk, seperti: polusi, penyalit lingkungan, kelaparan, ancaman cadangan pertambangan, pengangguran, pemukiman yang berdesakan, terancamnya spesies flora dan fauna, urbanisasi, inflasi, bahkan sengketa politik. ${ }^{32}$

32Diskusi tentang hal ini baca selanjutnya, Lester E Brown et.all, Twenty Two Dimentions of the populations Problems (Washington: tp., 1976). 


\section{Ekonomi Kapitalisme}

Prinsip kapitalisme memandang alam dan segala sumber daya alam sebagai objek eksploitasi tanpa batas. Dalam sejarahnya ada tiga tokoh yang sangat berpengaruh dalam lahir dan berkembangnya kapitalisme ini. Tokoh pertama adalah Martin Luther yang telah meletakkan dasar-dasar teosofik kapitalisme, selanjutnya muncul Benjamin Franklin yang meletakkan dasar-dasar filosofis. Konsep kapitalisme semakin matang dengan munculnya bentuk detail dasar-dasar ekonomi kapitalisme oleh Adam Smith.

Ada lima prinsip fundamental kapitalisme yang kalau dianalisa lebih lanjut sebenarnya tidak pro terhadap konservasi lingkungan. Pertama; pengakuan penuh pada hak milik individual tanpa batas-batas tertentu, kedua; pengakuan penuh untuk melakukan kegiatan ekonomi demi meningkatkan status sosial dan ekonomi, ketiga, pengakuan adanya motivasi dan inspirasi dalam ekonomi untuk meraih keuntungan semaksimal mungkin, keempat; pengakuan terhadap kebebasan dalam melakukan kompetisi dengan individu lain dan kelima; pengakuan terhadap berlangsungnya hukum ekonomi pasar bebas atau mekanisme pasar. ${ }^{33}$

Hardin dalam The Tragedy of the Commons melihat bahwa alasan-alasan ekonomi seringkali menggerakkan perilaku manusia atau keputusan-keputusan yang diambil oleh manusia secara perorangan maupun dalam kelompok, terutama dalam hubungannya dengan pemanfaatan common property. Common property adalah sumber-sumber daya alam yang tidak dapat menjadi hak perorangan, tetapi setiap orang dapat menggunakan atau memanfaatkannya, meliputi sungai, padang rumput, udara, laut. Karena sumber daya itu dapat dan bebas untuk dimanfaatkan oleh setiap orang, maka setiap orang berusaha untuk memanfaatkan atau mengeksploitasi sumber daya semaksimal mungkin guna memperoleh keuntungan pribadi yang sebesar-besarnya. Jadi adanya kebebasan untuk

33Y. Eko Santoso, Menuju keselarasan Lingkungan; Pandangan Teologis Terhadap Pencemaran Lingkungan (Malang: Averroes Press, 2003), 26. 
mengeksploitasi sumber daya alam akan membawa kehancuran bagi masyarakat. Keadaan inilah yang oleh Hardin disebut dengan tragedy of the commons. ${ }^{34}$

A. Sonny Keraf dengan tegas menyebut bahwa ekonomi global telah melahirkan krisis lingkungan. Secara jitu ia menunjukkan bagaimana negara-negara maju menerapkan strategi ekonominya untuk terus menjajah dunia ketiga melalui organisasi-organisasi ekonomi dunia. Pada awalnya strategi itu dimainkan oleh World Bank dan IMF dengan strategi utang luar negerinya. Kemudian melalui organisasi perdagangan dunia (WTO) dengan berbagai institusinya (GAAT, TRIPS, dan GAT), mereka mengeruk kekayaan alam dan kekayaan intelektual dunia ketiga dengan menciptakan ekonomi global dan pasar bebas. Lembaga-lembaga tersebut tidak ramah terhadap manusia penghuni dunia ketiga karena akhirnya berkembang menjadi polisi dagang dunia yang hanya menjaga agar tidak ada "pemain" yang dirugikan, bukan menjaga agar tidak ada yang dirugikan. 35

Dari uraian di atas, nampak jelas bahwa ekonomi kapitalisme tidak memberikan ruang pada prinsip-prinsip nilai, moral, dan etika, bahkan kapitalisme melihat segala sesuatu dengan cara pandang (worldview) serba materi dan jauh dari nilai-nilai spiritual yang transenden. Berbagai efek negatif ditimbulkan oleh kapitalisme ini di antaranya munculnya kesenjangan ekonomi antarmasyarakat (unequality), mekanisme yang eksploitatif, serakah, dan pola hidup konsumerisme karena tidak adanya kontrol terhadap sistem tersebut. Dan yang paling parah adalah munculya alienasi individualistik karena tersingkir dari kompetisi mekanisme pasar.

Sebagai antitesis terhadap kelemahan kapitalisme, pada abad 19 muncul Karl Marx dengan sistem sosialismenya, namun kehadiran konsep ini ternyata tidak jauh berbeda dengan efek

${ }^{34}$ Berbagai ulasan mengenai hubungan pembangunan terkait dengan Lingkungan Hidup, selanjutnya lihat Emil Salim, Lingkungan Hidup dan Pembangunan (Jakarta: Mutiara, 1979), Lihat Juga Emil Salim, Pembangunan berwawasan Lingkungan, (Jakarta: LP3ES, 1986).

35A. Sony Keraf, Etika Lingkungan (Jakarta: Kompas, 2006), 225. 
yang ditimbulkan oleh kapitalisme, bahkan sosialisme mengalami kekalahan dari sosialisme; negara-negara sosialis seperti Rusia dan Jerman Barat justru makin terpinggirkan. ${ }^{36}$

Menghadapi berbagai permasalahan pertumbuhan penduduk dan laju pertumbuhan ekonomi, The Club of Rome mengusulkan sebuah solusi yang disebut dengan Zero Growth (pertumbuhan nol). Dengan demikian di samping dinamika pertumbuhan penduduk Zero Population Growth (ZPG), maka laju pertumbuhan ekonomi juga harus nol (zero). ${ }^{37}$

\section{Worldview atau paradigm}

Cara pandang (worldview) suatu kelompok masyarakat amat berpengaruh dalam menentukan sikap dan perilaku mereka terhadap alam dan lingkungannya. Sebahagian pakar berpendapat bahwa timbulnya masalah-masalah lingkungan disebabkan oleh wolrdview (cara pandang) yang berlaku menempatkan kepentingan manusia sebagai pusat dari segalagalanya dalam alam semesta. Nilai dari segala sesuatu yang ada di alam semesta dilihat dari kepentingan manusia semata. Tata nilai yang dimiliki ini dikenal dengan istilah anthropocentric atau bomocentric.

${ }^{36}$ Ada beberapa letak kelemahan sosialisme dalam mengatasi ekonomi kapitalis, diantaranya pertama: sistem ini telah menjadi otoriter, kedua: bersifat mematikan kreatifitas individual karena keinginan menghilangkan dimensi individual dalam kapitalisme, ketiga: akibat hilangnya fungsi kontrol sosial akibat kekuatan otoriter mekanisme ekonomi, keempat: prinsip kelas dalam sosialisme telah membentuk ketegangan dan kesenjangan antar kelas, kelima: penurunan derajat dan kualitas manusia karena dianggap sebagai barang industri yang bebas dieksploitasi. Selanjutnya lihat Muhsin Jamil, "Etika Ekonomi Islam", Jurnal Teologia, No.12, Januari 1992.

${ }^{37}$ Secara sederhana ZPG (Zero Population Growth) menuntut beberapa syarat yaitu: pertama, setiap pasang suami istri memiliki tidak lebih dari dua orang anak, sehingga setiap orang akan menggantikan dirinya. Kedua, memperbaiki status perempuan. Perempuan berkarir dan berpendidikan cendrung mempunyai anak sedikit di negara yang memungkinkan perempuan berpendidikan dan bekerja, sehingga laju pertumbuhan penduduk di negara bersangkutan lebih rendah dari pada di negara yang tidak menawarkan pilihan seperti itu kepada kaum perempuan. 
Berdasarkan wawasan pandang antroposentris, manusia bukanlah sebagian dari alam. Manusia adalah hasil daya cipta Tuhan. Selanjutnya, manusia itu diciptakan untuk mengatur dan menaklukan alam. Kaidah-kaidah yang berlaku di antara masyarakat manusia tidak berlaku terhadap benda-benda alam atau makhluk alam lainnya, seperti hewan dan tumbuhan. Dengan demikian wawasan pandang antroposentris menimbulkan dualisme antara manusia di satu pihak dan alam semesta serta makluk lainnya di lain pihak. Oleh sebab itu, eksploitasi terhadap alam semesta, menurut wawasan pandang antroposentris, harus dilihat sebagai perwujudan kehendak Tuhan. Manusia pada dasarnya diciptakan oleh Tuhan untuk menguasai dan menaklukkan alam.

Locke menyatakan teorinya dengan primary and secondary qualities. Baginya kualitas primer yang dapat hidup di alam, dan tidak ada tempat bagi kualitas skunder. ia mengatakan, nature is a dull affair, soundless, scentless, colorless; merely the burrying of material, endlessly, meaninglessly. 38

\section{Berbagai Ide dan Gerakan Konservasi Lingkungan}

Berbagai konferensi internasional tentang lingkungan hidup mulai dari konferensi lingkungan hidup di Stocholm (1972), Naerobi, dan Kenya (1982), diadakan sebagai respon atas kondisi daya dukung bumi yang semakin memprihatinkan. Upaya global pengurangan gas emisi rumah kaca sebenarnya telah dilakukan di antaranya dengan pembuatan kerangka konvensi untuk perubahan iklim Tahun 1992 di Rio Jeneiro Brazil yang ditandatangani 167 negara yang mengikat secara moral bagi negara-negara industri untuk menstabilkan emisi karbondiaoksidanya. Bahkan Setelah KTT Bumi di Rio De Jeneiro 1992, secara rutin setiap tahun digelar KTT Perubahan Iklim, dimulai pada tahun 1995 COP (Conference of Parties) 1 di Berlin, Jerman, COP ke-2 di Jenewa, Swiss pada Juli 1996, COP

${ }^{38}$ A.N. Whitehead, Science and The Modern World (New York Macmillan Compan, 1926), 79. Adapun kritik tentang tero qualitas Locke selanjutnya lihat David Ray Griffin, God and Religion in the Postmodern world; Essays in Post Modern Theology (Albany: State University of New York Press, 1989), 16. 
ke-3 di Kyoto, Jepang 1997, sampai COP ke-13 di Bali, Indonesia pada 3 - 15 Desember 2007, COP ke-14 di Poznań, Polandia dan COP ke-15 di Denmark 2009.

Berbagai KT'T tersebut dianggap belum mampu menghasilkan kata sepakat antara ngara berkembang dan negara maju. KTT terkini di Denmark juga harus berakhir tanpa membuahkan kesepakatan utama dengan tidak menyebutkan batasan waktu dan angka target pengurangan emisi gas negara maju pada Tahun 2020, sehingga jalan menuju gerakan global penyelamatan lingkungan makin tidak mudah.

Dewasa ini para environmentalist mulai melirik spiritualitas agama dan tradisi suku asli sebagai basis etika bagi konservasi lingkungan, karena hal tersebut dianggap sebagai kesadaran yang paling mendasar yang tertanam dalam benak manusia yang akan mendorong dan memotivasi bahkan memengaruhi tingkah laku manusia dalam berinteraksi dengan alam.

Setelah dirasakan tidak ada perubahan yang signifikan dengan diadakannya berbagai konvensi tentang lingkungan, akhirnya timbul kesadaran baru yang mengaitkan prinsip agama yang diharapkan berperan dalam menanggulangi krisis ekologi. Sains, dan teknologi memang diperlukan, tetapi itu saja tidak cukup.

Mary Evlyn Tucker besama John A. Grim menjadi pelopor untuk forum agama dan lingkungan dan membawa diskursus ini dalam berbagai kegiatan dari tingkat lokal dan internasional untuk menghimbau supaya agama-agama terlibat dalam menyelamatkan bumi. Agama, menurut Evlyn, mempunyai lima resep dasar untuk menyelamatkan lingkungan dengan 5R, yaitu Reference, Respect, Restrain, Redistribution, dan Responsibility. ${ }^{39}$ Begitupun dengan Vasudha Narayan, ia menyebutkan 3T sebagai modal dasar yang dapat menjadi sumber pemecahan masalah lingkungan berbasis agama yaitu: Text, Temple, dan Teacher. ${ }^{40}$

${ }^{39}$ Mary Evelyn Tucker, Hinduism and Ecology (Cambrigde: Harvard University Press, 2000), 12.

${ }^{40}$ Vasudha Narayan, Water, Wood and Wisdom; Hindu Ecological Perspectives dalam Harold Coward and Daniel McGuire, eds. Vision of The Earth (New York: State University of New York Press, 2000). 
Seyyed Hossein Nasr menegaskan tentang perlunya merengkuh kembali spiritualitas bagi manusia modern untuk mengatasi krisis lingkungan. Nasr mengatakan bahwa krisis ekologis dan pelbagai jenis kerusakan bumi yang telah berlangsung sejak dua abad yang lalu berakar pada krisis spiritual dan eksistensial manusia modern karena menangnya bumanismeantroposentris yang memutlakkan manusia. ${ }^{41}$ Dalam beberapa karyanya seperti: Islam and the plight of Modern Man (1975), An Introduction to Islamic Cosmological Doctrines (1978), Religion and the Order of Nature (1996), Man and Nature: The Spiritual Crisis in Modern Man (1997), Nasr menjelaskan sebab-sebab utama munculnya krisis lingkungan pada peradaban modern seraya menekankan pentingnya perumusan kembali hubungan manusia, alam dan Tuhan yang harmonis berdasarkan spritualitas dan kearipan perenial. Nasr menjelaskan bahwa dalam pandangan modernisme, kosmos atau alam hanyalah kumpulan benda mati (layaknya sistem jam dan mesin), materi yang tidak bernyawa, tidak berperasaan dan tak bernilai apa-apa, kecuali hanya nilai kegunaan ekonomis. Alam telah diperlakukan oleh manusia layaknya pelacur (prostitute) yang dieksploitasi tanpa rasa kewajiban bertanggung jawab terhadapnya. ${ }^{42}$

${ }^{41}$ Seyyed Hossein Nasr mengatakan bahwa Barat telah menjadi pemuja ilmu dan teknologi, sehingga tanpa disadari integritas kemanusiaannya telah tereduksi dan terperangkap pada jaringan sistem rasionalitas teknologi yang sangat tidak manusiawi. Dalam konteks ini, Nasr menggunakan dua istilah pokok yaitu axis dan rim atau center dan periphery. Menurutnya manusia modern telah berada di pinggiran (rim/periphery) eksistensinya dan bergerak menjauhi pusat (center/axis) eksistensinya. Selanjutnya lihat, Islam and Plight of Modern Man (London and New York, Longman, 1975), 4. Dalam kesempatan lain, Nasr mengkritik epistemologi Barat Modern yang hanya mengandalkan akal yang lepas dari yang sakral, Selanjutnya lihat Seyyed Hossein Nasr, Knowledge and The Sacred (Albany: State University of New York Press, 1989), 84.

${ }^{42}$ Seyyed Hossein Nasr, Man and Nature, The Spiritual Crisis of Modern Man (George Allen \& Unwin, Ltd. London, 1976), 18. Lihat Juga Nasr, Knowledge, 45. Selanjutnya lihat Sorjani, Lingkungan Hidup (The Living Environment) (Jakarta: Yayasan Institut Pendidikan dan Pengembangan Lingkungan (IPPL), 2005) dan Sony A. Keraf, Etika Lingkungan (Jakarta: Buku kompas, 2002). 
Dalam bentuk ekpresi yang lain, Nasr mendeskripsikan bahwa bumi kita sedang menderita dan berdarah-darah oleh luka-luka yang dideritanya akibat ulah manusia yang sudah tidak lagi ramah padanya, bahkan sebenarnya akar dari krisis tersebut bersumber dari tidak harmonisnya hubungan manusia dengan Tuhan. ${ }^{43}$ Pandangan sekuler dan ilmu pengetahuan serta teknologi yang tercerabut dari akar-akar spiritualitas dan agama, membuat bumi kian mengalami kritis dan terus menghampiri titik kehancurannya. Karena itu, peran agama untuk membantu mengatasinya merupakan sesuatu yang signifikan. ${ }^{44}$

Menurut Nasr, nilai-nilai agama dan kearifan-kearifan moral - yang ia sebut sebagai Ecotheology - sangat diperlukan untuk merawat keseimbangan dan keberlanjutan bumi. ${ }^{45}$ Ajakan Nasr mengisyaratkan agar umat Islam juga memberikan kontribusi pemikirannya dalam masalah konservasi lingkungan. Hal ini berarti umat Islam ditantang untuk menggali rumusan konsepkonsep utama tentang pelestarian alam, membahasakannya dalam konsep ekologi modern dalam bentuk karya-karya dan selanjutnya dipraktikkan sebagai panduan moral dalam realitas kehidupan sehari-hari.

Ada dua agenda profetis perenial Islam yang mendesak untuk dirumuskan terkait dengan krisis lingkungan menurut Nasr. Pertama, memformulasikan dan memperkenalkan sejelasjelasnya, dalam bahasa kontemporer, hikmah perenial (philosophia perennis) Islam tentang tatanan alam, signifikansi religiusnya, dan kaitan eratnya dengan setiap fase kehidupan. Kedua, menumbuhkan dan mengembangkan kesadaran ekologis yang berperspektif teologis (eco-theology), dan jika perlu, memperluas wilayah aplikasinya sejalan dengan prinsip syariah (agama) itu sendiri.

\footnotetext{
${ }^{43}$ Selanjutnya lihat Seyyed Hossein Nasr, Man in The Universe; The Islamic View, (London: Longman,), 115 dan Nasr, Man, 20.

${ }^{44}$ Seyyed Hossein Nasr, Religion and the Order of Nature (New York: Oxford Univbersity Press, 1996), 3.

${ }^{45}$ Ibid., 29. Selanjutnya lihat, Martin Palmer, Faith in Concervation: New Approaches to Religions and the Environment (The World Bank, 2004) dan David E.Coover dan Joy A.Palmer (eds.), Spirit of the Environment; Religion, V alue and Environmental Concern (Londen, Routledge, 1998).
} 


\section{Prinsip-prinsip Ecotheolgy Islam}

Menurut C.A. Qadir, terdapat 750 ayat atau sekitar seperdelapan dari semua ayat Kitab Suci al-Qur'an yang mendorong kaum beriman untuk menelaah, merenungkan, dan menyelidiki alam. ${ }^{46}$ Menganalisis turunnya wahyu periode pertama di Makkah, maka kita akan temukan bahwa tujuan utamanya adalah membangunkan kesadaran manusia terikait hubungannya dengan Tuhan dan alam. Sehingga terlihat jelas tahapan-tahapannya, yaitu merubah keseluruhan worldview (politeis dan paganism) Arab, kemudian mengkonstruk image mereka dan tahap terakhir merubah sikap (attitude), serta perasaan (feelings) mereka dalam kehidupan realitas terkait dengan hubungan mereka dengan Tuhan dan alam.

Konteks ini menurut Ozdemir diperjelas dalam turunnya wahyu pertama (Qs. al-'Alaq [96]: 1-5). Ada Makna tersembunyi yang dapat ditangkap dari paham tentang nabi seorang ummi (not literate) dan fakta bahwa waktu itu tidak ada teks yang dapat dibaca seperti perintah Jibril (iqra') untuk membaca. Makna tafsir yang dapat dipahami yaitu, bahwa "baca" dalam konteks ini berati perintah untuk "membaca" ayat-ayat Tuhan berupa alam dengan segala makhluk-Nya. Manusia harus menyadari bahwa semua alam tercipta sebagai manifestasi realitas Ilahi. ${ }^{47}$ Dalam beberapa ayat juga berulangkali ditekankan tentang alasan eksistensi alam dan tujuan penciptaannya. Bahkan al-Qur'an menantang kaum Pagan Arab (who were illiterate) menganalisa dan mempertimbangkan alam minimal dari dua alasan; pertama, memikirkan eksistensi dan kehadiran Tuhan dalam segala bentuk ciptaan-Nya; kedua, untuk memiliki kesadaran moral dan tanggung jawab terhadap wujud transenden. Lebih dari itu, Ozdemir menyebutkan bahwa al-Qur'an menyebutkan alam dan

${ }^{46}$ C. A. Qadir, Philosophy and Science in the Islamic World (London: Routledge, 1988).

${ }^{47} \mathrm{Ibrahim}$ Ozdemir, Toward an Understanding of Environmantal Ethics from a Qur'anic Perspective, dalam Richard Foltz, Islam and Ecology; A Bestowed Trust (USA: The President and Fellows of Harvard College, 2003), 7. 
berbagai spesies dengan menggunakan istilah ummat (community) seperti manusia juga (Qs. al-An'àm [6]:38).48

Al-Qardhawi menyebutkan bahwa penamaan surat-surat alQur'an dengan berbagai nama spesies tumbuhan dan hewan, tanah, air, udara, dan sumber alam seperti pertambangan adalah merupakan simbol-simbol yang mengarah pada petunjuk kepada manusia untuk ramah dan menjaga harmonisasi dengan lingkungan. Dalam al-Qur'an ditemukan nama hewan seperti surat al-Baqarah (sapi), al-An'àm (binatang), al-Fill (gajah), al'Ádiyät (kuda), al-Naml (semut), al-Nạ̣l (Lebah), al-'Ankabūt (laba-laba) dan nama-nama tumbuhan seperti al-Tin (sebangsa tumbuh-tumbuhan), al-Hadid (barang tambang), atau nama ekosistem lainnya seperti al-Dhäriyät (angin), al-Najm (bintang), al-Fajr (fajar), al-Shams (matahari), al-Layl (malam), al-Ḍụ̄ā (waktu Duhạa), al-'Așr (waktu sore) ${ }^{49}$.

Al-Qur'an menarasikan bahwa tujuan penciptaan alam ${ }^{50}$ adalah untuk pemenuhan kebutuhan manusia (Qs. al-Jāthiyah

${ }^{48}$ Ozdemir, Toward, 23.

${ }^{49}$ Yusuf al-Qardhawi, Islam Agama Ramah Lingkungan (Jakarta: Pustaka al-Kautsar, 2002), 77. Diantara sekian banyak seruan agama untuk ramah terhadap lingkungan terdapat dalam Qs. al-Rūm [30]: 41, Qs. al-Baqarah [2]: 11-12, 27, 60, 205, Qs. Āli 'Imrān [3]: 63, Qs. al-Māidah [5]: 32-33, 64,.Qs. al-A'rāf [7]: 56, 74, 85, Qs. Hūd [11]: 85, 116, Qs. al-Ra'd [13]: 25, Qs. alNahl [16]: 88, Qs. al-Syu'arā [26] 151-152, 183, Qs. al-Qaṣaṣ [28]: 77, 83, Qs. al- 'Ankabūt [29]: 36 dan Qs. al-Ṣād [38]: 28.

${ }^{50}$ Dalam al-Qur'an ada beberapa istilah yang biasa digunakan dan terkait dengan makna lingkungan, diantaranya: al-'älamin (seluruh spesies), al-samä' (ruang dan waktu), al-ard (bumi) dan bìah (lingkungan). Kata al-'álamin digunakan dalam al-Qur'an sebanyak 71 kali dalam bentuk frase dan gabungan kata. Sedangkan kata al-samä' digunakan sebanyak 387 kali (210 bentuk jamak dan 177 bentuk tunggal). Adapun kata al-ard digunakan sebanyak 463 kali. Penggunaan kata ini mempunyai dua variasi makna. Pertama, bermakna lingkungan planet bumi yang sudah jadi dengan konotasi tanah sebagai ruang tempat orgasme atau jasad renik, wilayah tempat kehidupan manusia dan fenomena geologis. Kedua, bermakna lingkungan planet bumi dalam proses menjadi yakni proses penciptaan dan kejadian planet bumi. Sedangkan kata al-bïah disebut dalam al-Qur'an sebanyak 15 kali. Kata al-bìah bermakna lingkungan, meskipun ia mempunyai makna lain seperti berulangkali, memancing atau mengundang, dan berkonotasi pulang kembali. Kata al-bìab yang bermakna lingkungan terdapat dalam Qs. 3:21, 
[45]:13), sehingga dalam konteks ayat ini manusia diperintahkan untuk mengelola dan memanfaatkan alam dengan cara yang baik dan sesuai dengan aturan yang ditetapkan oleh Allah swt. Namun terkadang ayat inilah yang sering menjadi landasan teologis untuk melegitimasi pengeksplotasian alam oleh manusia.

Aturan pengelolaan dan pemanfaatan alam oleh manusia sebenarnya dibingkai dan dibatasi dengan perintah untuk tidak berbuat kerusakan, tidak serakah dan menyia-nyiakannya, tidak mengeksploitasi, tidak boros (berbuat mubazir), (Qs. al-A'rāf [7]:31 dan Qs. al-Isrā [17]:27). Islam melarang pemanfaatan alam yang mengarah pada eksploitasi dan pengerusakan alam, spesies tumbuh-tumbuhan dan hewan serta mikroorganisme lainnya.

Dalam perspektif tasawuf, alam adalah manifestasi dari seluruh nama-nama dan sifat-sifat Allah. Misalnya tumbuhtumbuhan merefleksikan sifat-sifat ilahi berupa pengetahuan karena tumbuh-tumbuhan tahu bagaimana menemukan makanan dan cahaya, buah-buahan memanifestasikan anugerah dan karunia Allah, dan hewan mencerminkan empat sifat ilahi yaitu kehidupan, pengetahuan, keinginan, dan kekuasaan. ${ }^{51}$

Selain ayat-ayat ekologis yang normatif di atas, sesungguhnya dalam perspektif historis Islam terdapat prinsip-prinsip konservasi alam yang sudah dipraktikkan oleh Nabi Muhammad saw. empat belas abad yang lalu, termasuk dalam pengaturan tata kota, pertumbuhan populasi dan pemeliharaan sumber daya alam. Dalam Islam dikenal adanya kawasan ḩaram, yaitu kawasan yang diperuntukkan untuk melindungi sumber daya agar tidak diganggu. Di samping itu, Nabi menetapkan daerah-daerah yang tidak boleh diganggu dan dilanggar aturan ekosistemnya, membatasi aliran-aliran air, memelihara beberapa fasilitas umum dan kota-kota tertentu. Di dalam kawasan haram, fasilitas umum

Qs. 7:74, Qs. 10:93, Qs. 12:56, Qs. 16:41, dan Qs. 29:58. Dalam konteks ini dapat dipahami bahwa alam atau lingkungan bukanlah benda yang tidak berarti apa-apa dan tidak mempunyai tujuan penciptaan. Alam adalah tanda (ayat) "keberadaan" Tuhan. Alam menjadi petunjuk dan jalan untuk sampai pada pengetahuan tentang diri Tuhan. Qs. 51:20, dan Qs. 41:53.

${ }^{51}$ Sachiko Murata, The Tao of Islam; A Sourcebook on Gender Relationships in Islamic Thoughts, (Albany: State Univerity of New York Press, 1992), ter. (Bandung: Mizan, 1998), 64. 
seperti sumur (penampungan air) harus dilindungi dari kerusakan. Ruang untuk operasi dan pertahanan sumur juga disediakan, termasuk melindungi airnya agar tidak terkena polusi. Nabi menyediakan tempat beristirahat bagi ternak serta menyediakan ruang bagi fasilitas-fasilitas irigasi. ${ }^{52}$

Selain beberapa terma etimologi ekologi di atas, dalam tradisi pemikiran Islam ditemukan juga beberapa prinsip dasar yang terkait dengan lingkungan dan dapat dijadikan sebagai basis bagi elaborasi konsep ekologi dalam Islam. Diantara prinsip tersebut adalah:

\section{Tawhid: unity of all creation}

Semua agama, pemikiran atau aliran filsafat pasti mempunyai sebuah paradigma atau worldview, dan worldview tersebut dapat menjadi dasar ideologi sebuah agama apabila ia memiliki ketegasan dan keluasan wawasan pemikiran. Dalam agama Islam, Tawhī ${ }^{33}$ merupakan basis atau kerangka dasar bagi keseluruhan pandangan dan worldview-nya. ${ }^{54}$

Tawhidd adalah poros yang di sekelilingnya semua ajaran Islam bergerak dan berputar. Tawhịd seperti khazanah yang dipadatkan, yang dipermukaannya nampak sederhana, namun apabila dibentangkan dan dibeberkan akan meliputi seluruh Islam. ${ }^{55}$

${ }^{52}$ Sardar, Islamic, 240.

${ }^{53}$ Secara etimologis, tawhid berasal dari kata waḥhada, yuwaḥhidu, tauhidan yang berarti esa, keesaan, atau mengesakan, yaitu mengesakan Allah meliputi seluruh pengesaan. Dalam beberapa konteks juga digunakan dalam arti "mempersatukan" hal-hal yang berserakan atau terpecah-pecah, misalnya penggunaan tawhidul Quwwah dalam bahasa Arab yang bermakna mempersatukan seluruh kekuatan. Dalam al-Qur'an memang tidak ditemukan kata "tawhìd" (dalam bentuk masdar), istilah ini sesungguhnya merupakan formulasi awal dari para teolog untuk menginterpretasikan kemahaesaan Tuhan.

${ }^{54}$ Murtadha Mutahhari, Fundamentals of Islamic Thought (Berkeley: Mizan Press, 1985).

${ }^{55}$ Muhammad Taqi Misbah Yazdi, At-Tawhid or Monotheism, As in the ideological and The value system of Islam (Iran; Islamic Propagation organization, tt), h. 15, Lihat juga, Muhammad Taqi Misbah Yazdi, The Learnings of the Glorious Qur'an, ter. Filsafat Taubid, M. Habib Wijaksana (Bandung: Arasy, 2003), 59. 
Tawhid menurut Nasr adalah jantungnya Islam (the heart of Islamic life). Dan hidup yang bermanfaat adalah hidup yang mampu merealisasikan makna prinsip Tawhid ke dalam realitas hidup, yaitu meraih dan menyatukan berbagai keragaman (mutiplicity) dalam bingkai kesatuan (unity). ${ }^{56}$ Pada jantung ajaran Islam inilah (baca: tawhicd) terdapat realitas Tuhan Yang Maha Esa, Yang Absolut dan Tidak Terbatas, Yang Maha Pengasih dan Maha Penyayang, Zat Yang Maha Tinggi sekaligus Kekal, lebih besar dari semua yang dapat dipikirkan dan dibayangkan.

Islam dalam pengertian syariat Nabi Muhammad, sesungguhnya tidak mempunyai hubungan khusus atau spesial dengan tawhid, karena tawhìd merupakan risälah yang dibawa oleh setiap nabi. (Qs. 21: 25) ${ }^{57}$, dengan demikian sesungguhnya tawhid telah menjadi intisari (core) untuk setiap agama-agama yang datang sebelum kedatangan Islam yang dibawa oleh Muhammad.

Hakikat tawhid adalah penyerahan diri yang bulat kepada kehendak Tuhan, baik menyangkut ibādah maupun mu'ämalah, dalam rangka menciptakan pola kehidupan yang sesuai dengan kehendak Allah. Dengan demikian tawhïd harus menjadi dasar seluruh konsep dan aktifitas umat Islam, baik ekonomi, politik, sosial maupun budaya.

Pemaknaan tawhid harus melampaui pembicaraan logisrasional yang sering hanya mengambang pada tataran teori tanpa nilai dan tanpa diikuti eksistensi pelaksanaan praktis. Pemaknaan tawhid-pun tidak hanya terbatas pada definisi serta perdebatan golongan fuqaha, filsuf dan teolog mengenai inti pokok ketuhanan dalam Islam, tetapi tawhid lebih kepada keyakinan serta pengalaman religius yang mampu melingkupi wilayah transenden dan praktis sekaligus secara bersamaan tanpa adanya kontradiksi pada wilayah sosial, politik, dan sains.

Cara pandang yang berbasis tawhid melihat segala sesuatu dalam alam ini bersumber dari Allah dan akan kembali kepada Allah, bahkan semuanya mengelilingi Allah. Alam ini diciptakan

${ }^{56}$ Seyyed Hossein Nasr, The Heart of Islam; Enduring V alues for Humanity (New York: HarperSanfransisco, 2002), 6.

${ }^{57}$ Sachiko Murata dan William C. Chittick, The Vision of Islam (USA: Paragon House, 1994), 45. 
dan didesain oleh Allah dengan tujuan dan keberlangsungan atau pemeliharaannyapun di jaga Allah. Alam semesta dan segala mahkuk yang ada di dalamnya adalah merupakan irädah (kehendak) suci Allah yang diciptakan dengan tujuan sebagai jalan atau petunjuk untuk sampai kepada-Nya. Chittick mengatakan:

God the Ultimate reality is One, and everything other than God comes from God and is related to Him. No true understanding of anything is possible unless the object in view is defined in relationship to the divine. All things are centered on God. ${ }^{58}$

Tawhid dalam istilah Fazlun Khalid merupakan kesaksian (syahädab) primordial tentang kesatuan semua makhluk (the primordial testimony to the unity of all creation), tawhid juga merupakan simbol kesatuan bagi seluruh ciptaan Allah (symbolic of the unity of creation), ${ }^{59}$ mulai dari tingkatan terkecil seperti bagian mineral, tumbuhan, hewan, binatang, manusia dan alam kosmos lainnya. Konsep ini menunjukkan kesatupaduan seluruh alam dan isinya yang terangkai dalam bingkai (frame) asal dan sumber yang sama serta tujuan yang sama.

Pandangan Fazlun di atas, senada dengan apa yang ditafsirkan oleh Sayyid Quțub dengan mengatakan bahwa pemahaman terhadap tawhid tidak boleh berhenti pada makna generiknya saja (dalam bingkai aqidab), yaitu mengesakan Allah (unity of goehead/wahdaniyat), melainkan harus berderivasi pada konsep kesatuan penciptaan (unity of creation/wabdat al-Khäliq alMudabbir), kesatuan kemanusiaan (unity of mankind/wabdat alinsāniyat), kesatuan tuntunan hidup (unity of purpose of life/wahdat nibātul hayāt). ${ }^{60}$

Dalam Islam, tawhid merupakan sumber fundamental dari semangat ilmiah dalam seluruh wilayah pengetahuan, bahkan

${ }^{58}$ William. C. Chittick, Article, 'The Concept of Human Perfection. from, The World \& I. New York; News World Communications (Feb. 1991). 500

${ }^{59}$ Fazlun Khalid, "Islam and the Environment", in: Timmerman, P. (ed) Encyclopedia of Global Environmental Change (Chichester: John Wiley \& Sons Ltd, 2002), 337.

${ }^{60}$ Sayyid Quțub, Tafsìr Fì Zilāl al-Qur'àn, Jilid 7 (Beirūt: Ihyyā al-Turath al-'Arabīi, 1971), 153 
tawhid merupakan pengetahuan tertinggi yang merupakan pengetahuan tentang esensi, nama-nama, dan sifat-sifat Ilah serta pengetahuan tentang efek-efek dan tindakan Ilah yang meliputi semua ciptaan Tuhan. ${ }^{61}$

Konsep tawhid dinyatakan dengan cara yang paling universal dalam bentuk "kesaksian" (syahādah). Pertama, "là ilāha illallāh", yang secara generik diterjemahkan sebagai "tiada tuhan selain Allah" (there is no god but God). Implikasi dari doktrin ini adalah keharusan bagi setiap muslim untuk merealisasikan prinsip dasar dan ruh dari tawhid dalam berbagai jenis pengetahuan, ide, konsep, dan teori, bahkan harus meresap ke dalam setiap praktik kehidupan realitas sosial kultural manusia. ${ }^{62}$ Sehingga pikiran dan tindakannya menjadi sebuah keutuhan yang harmonis dan sebuah kesatuan utuh.

Ketika kesatuan tersebut tercapai, maka tidak ada lagi perbedaan dan kesenjangan antara wilayah pikiran maupun tindakan, antara spiritual dan temporal atau antara hal-hal yang berifat duniawi dan ukhrawi.

Bagi seorang Muslim, Tuhan tidak hanya sekedar hadir namun Tuhan menjadi kunci dari hukum (core of normativeness) segala aspek kehidupan. Pengalaman religi yang berujung pada core of normativeness hingga muncul iman yang kritikal dan rasional. Pada intinya tawhid terdiri dari lima prinsip yaitu duality, ideationality, teleology, capacity of men and malleability of nature, responsibility dan Judgment. ${ }^{63}$

Dalam perspektif Islam tradisional menurut Nasr, makna syahädah dalam kalimat Là Iläha Illa Alläh adalah bahwa tidak ada yang mutlak kecuali Allah, jadi satu-satunya yang mutlak adalah Allah. Manusia walaupun dipandang sebagai khalifah Allah atau mahluk teomorfis dalam bentuk perefleksian nama-nama dan kualitas Tuhan secara langsung dan sentral; tidaklah menjadikan dia menjadi mutlak pada dirinya sendiri. Dalam kenyatannya,

${ }^{61} \mathrm{Osman}$ Bakar, Tauhid and Science; Islamic Perspectives on Religion and Science (Cambridge: The Islamic Text Society, 1998), 2.

62Sardar, Islamic, 225.

${ }^{63}$ Ismail Raji al-Faruqi, Al Tawhid: Its Implications for Thought and Life (Virginia, USA: International Institute of Islamic Thought, 1992), 10. 
kualitas positif apapun yang dimiliki manusia berasal dari Tuhan. Itulah sebabnya mengapa dalam al-Qur'an ditegaskan Tuhanlah yang kaya dan kamu sekalian miskin. (Qs. Muhammad [47]:38) ${ }^{64}$

Selanjutnya menurut Nasr, kemenangan terbesar manusia terletak dalam kesadaran akan kemiskinan ini, yang hanya melaluinyalah ia mampu menggapai Yang Mutlak. Dalam konteks inilah, Nasr mengkritik Humanisme Barat yang telah memutlakkan manusia modern sambil meminggirkan manusia dari pusatnya dan membangun kebudayaan dan kesenian yang benar-benar tidak memiliki pusat (center-less), humanisme Barat telah mencoba memberikan kualitas kemutlakan kepada manusia yang tanpa pusat itu.

Humanisme, rasionalisme, dan berbagai aliran sains modern pada abad ke-17 inilah yang selanjutnya membentuk paradigma manusia modern menjadi manusia yang memiliki hak-hak mutlak untuk menguasai dan mengeksploitasi alam. Humanisme menurut Nasr, memandang manusia mutlak, sehingga Tuhan maupun alam tidak mempunyai hak.

Implikasi lainnya adalah lahirnya worldview manusia modern yang fragmented and consciousness sehingga memandang segala sesuatu sebagai 'accident' atau kebetulan belaka, yang terpisahpisah, yang terfragmentasi, yang tidak berhubungan satu dengan lainnya. Dan sifat dari ilmu pengetahuan modern seperti inilah yang telah menjadi penghambat manusia untuk memahami keutuhan realititas dirinya dan semua yang ada di sekitarnya.

Konsep perenial Islam tidak pernah memutlakkan hak-hak manusia atas Allah dan ciptaanNya, sebaliknya mereka menentang keras pemutlakkan tersebut dan selalu hidup dalam kesadaran akan hak-hak Tuhan dan hak-hak makhluk lainnya, termasuk hewan, tumbuhan dan alam lainnya.

Osman Bakar menjelaskan bahwa kesatuan (unity) yang merupakan implikasi tawhid tersebut bisa terealisasi pada dua level yaitu level pikiran dan aksi. ${ }^{65}$ Pertama; Pada level pemikiran, kesatuan atau integrasi dicapai melalui aplikasi gagasan tentang

${ }^{64}$ Seyyed Hossein Nasr, Islam; Religion, History and Civilization (USA: Harpercollins books, 2003), 3 dan 59.

${ }^{65}$ Bakar, Taubid, 4. 
kesatuan dan hirarki pengetahuan serta eksistensi sebuah gagasan yang khas Islam, namun sebenarnya hal tersebut adalah hal yang lazim dalam semua peradaban tradisional. Kedua; pada level aksi, kesatuan dicapai melalui aplikasi syariah (hukum Ilahi) dalam Islam yang merupakan manifestasi konkret kehendak Ilahi. Hukum Tuhan ini selain mengandung prinsip-prinsip yang bersifat universal, namun juga mengandung rincian detail tentang cara-cara manusia harus bertindak dan berperilaku.

Ibn Arabi mengatakan bahwa alam ini tidak lain adalah manifestasi-manifestasi (tajalliyat) Allah, atau lebih tepatnya menifestasi-manifestasi sifat-sifat, nama-nama dan af'äl Allah. Pada dirinya, alam tidak memiliki realitas, Tuhanlah yang memberi realitas tersebut kepada alam, oleh sebab itu Tuhan adalah al-Haqq (realitas sejati). Pandangan Sufi ini juga senada dengan pandangan filsuf parepatetik, khususnya Ibnu Sina yang mengatakan bahwa alam pada dirinya adalah mumkin al-wujüd (sebuah potensial), jadi alam hanyalah sebuah potensi bukan aktualitas, karena itu belum memiliki realitas. Untuk dapat aktual alam membutuhkan (al-faqir dalam istilah Suhrawardi) Tuhan (alghaniy) untuk mengaktualkan potensinya..

Tawhid, dapat dijadikan sumber doktrin teologi ekologi. Semua alam semesta baik yang nampak ataupun tidak adalah merupakan tanda-tanda (āyät/sign) bagi Eksistensi Allah. Dan segala sesuatu merupakan manifestasi Allah, dan semuanya berasal dari-Nya. Konsep ini menurut Nasr terlihat dalam konsep iḅsān, yang merupakan jantung atau hati dari Islam. ${ }^{66}$ Iḅsān menimbulkan kesadaran bagi setiap manusia akan kehadiran Tuhan dalam setiap gerak dan langkahnya dalam menjalin relasi dengan alam dan makhluk lainnya.

Dewasa ini dibutuhkan satu paradigma baru dalam memahami konsep tawhid. Tawhid yang dipahami secara sempit hanya dalam bidang teologi (aqidah) harus dipahami berbeda dengan menjadikan tawhid tersebut lebih "membumi" bahkan menjadi sebuah key concept yang merupakan worldview atau weltanshaung Islam dalam menghadapai berbagai problema hidup, termasuk diantaranya krisis lingkungan.

${ }^{60}$ Nasr, The Heart, 314. 
Tawhid, seharusnya tidak terbatas pada afirmasi ketuhanan (man) saja, dan bukan hanya suatu pernyataan lisan (taqrirun bi allisān), tetapi tawhìd juga mengandung makna pembenaran dalam hati (tasdiqun bil al-qalbi) dan termanifestasikan dalam tindakan dan pola tingkah laku yang nyata dalam kehidupan sosial masyarakat ('amalun bi al-jawärib). Dengan demikian tawhìd harus meresap ke dalam segala bentuk pola tingkah laku manusia dalam berinteraksi dengan mahluk di alam ini. Roger Garaudy menegaskan bahwa tawhid bermakna keterlibatan prinsip tersebut dalam memberikan inspirasi dan motivasi kepada manusia dalam kehidupannya di dunia ini. ${ }^{67}$

Manusia harus melihat bahwa alam bukanlah entitas-entitas yang tidak mempunyai nilai sakral. Muslim harus meyakini bahwa alam dan segala makhluk yang menghuninya merupakan satu-kesatuan baik dari segi asal maupun tujuan. Dalam konteks krisis lingkungan, tawhid harus menjadi nilai dasar manusia dalam memahami alam ini. Alam harus dilihat sebagai ayat atau simbol yang dapat mengantarkan manusia untuk sampai pada realitas sejati. Alam memang diciptakan untuk manusia, namun berbagai hak yang dimiliki manusia hanya berupa hak pemanfaatan yang nantinya akan diminta pertanggungjawaban.

\section{Amānah}

Tuhan menyatakan bahwa alam semesta beserta segala isinya adalah milik-Nya (Qs. al-Baqarah [2]: 284). Manusia hanya berstatus pengelola dan pemelihara alam dalam kerangka pemenuhan tujuan yang telah direncanakan oleh Tuhan (Qs. alAḥqāf [46]: 3). Dari ayat di atas dapat dipahami bahwa alam ini bukanlah milik manusia. Kepemilikan manusia tersebut hanyalah bersifat amānah, titipan atau pinjaman yang pada saatnya nanti harus dikembalikan dengan pertanggungjawaban terhadap pemilik-Nya.

Manusia telah bersedia untuk menerima amānah yang diberikan Allah Swt. tersebut. Al-Qur'an menceritakan bahwa Tuhan sudah menawarkan amānah tersebut kepada semua

${ }^{67}$ Nasr, Islam, 87, dan Roger Garaudy, Mencari Agama abad XX, Ter. HM Rasjidi (Jakarta: Bulan Bintang, 1986), 304. 
makhluk seperti langit, bumi, gunung, namun semua menolaknya dan hanya manusia yang mau menerimannya. (Qs. al-Aḥzāb [33]: 72). Ayat ini membuktikan bahwa manusia mempunyai kedekatan (closeness) dengan Tuhan dan di sisi lain menunjukkan kesediaan manusia untuk menerima amānah Tuhan. Dari ayat ini juga dapat dipahami bahwa sesungguhnya manusia diberikan kebebasan (freedom) yang luas dan sekaligus tanggung jawab (responsibility) besar dalam mengemban kepercayaan yang telah diberikan oleh Allah kepadanya.

Dalam menafsirkan ayat di atas, Maulana Ali mengatakan bahwa manusia sesungguhnya mampu mengemban amānah tersebut, bahkan dia punya kekuatan (power) untuk menggunakan hak-hak tersebut pada tempatnya sesuai dengan tujuan dari pemberi hak tersebut, dan bukan sebaliknya dengan menyalahgunakannya (missuse) yang akan menyebabkan keseluruhan "konsep" pemberian amānah tersebut menjadi sia-sia (futile). ${ }^{68}$

Keunggulan, kekuatan, dan kontrol manusia terhadap mahluk lainnya, termasuk alam, merupakan bagian dari amānah yang telah diterima oleh manusia dari Allah. Manusia harus mampu menunjukkan tanggungjwabnya terhadap pemanfaatan dan pemeliharaan alam dan segala fasilitasnya dalam kerangka mengemban amānah yang telah diberikan Allah tersebut. Seandainya manusia tidak mampu menjalankan amānah tersebut bahkan menyalahgunakannya, maka manusia telah terjatuh dari seorang khalifah (leader) menjadi seorang yang zalim (a tyrant).

Nasr menegaskan bahwa hak pengelolaan dan pemanfaatan dan dominasi atas alam diberikan oleh Allah adalah dalam rangka mengemban amānah dan kepercayaan tersebut, tidak lebih dari itu. Ia mengatakan:

Nature has been given to man has a trust and nothing more. His rights of domination over it (is) only by virtue of his theomorphic make up, no as a rebel againts nature. ${ }^{69}$

${ }^{68}$ Abdullah Yusuf Ali, The Holy Qur'an; Text, Translation and Commentary (Maryland: Amana Corporation, 1989), 1080.

${ }^{69}$ Seyyed Hossein Nasr, The Encounter of Man and Nature (London: George Allen and Unwin Ltd. 1968), 96. 
Lebih tegas lagi Sardar mengatakan bahwa Allah menurunkan al-Qur'an dan syari'ahNya adalah dalam rangka bantuan bagi manusia untuk memenuhi amānah yang telah diterimanya. Sardar mengatakan:

The ultimate consequence of man's acceptance of trusteeship is the arbitration of his conduct by divine judgment. To be a Muslim is to accept and practice the injunctions of the Shariah. Thus the Shariah is both a consequence of one's acceptance of tawhîd and it is a path. ${ }^{70}$

Sebagai pengemban amānah seharusnya manusia tidak bertindak eksploitatif dan merusak alam yang akan menyebabkan manusia menerima murka Allah dan tergolong sebagai orang Zälim (Qs. al-Baqarah [2]: 60, 205, Qs. al-A'rāf [7]: 56, 85, Qs. al-Qașaș [28]: 88, Qs. al-Shu'arā [26]: 83), tidak boros dengan perilaku konsumtif terhadap sumber daya alam. (Qs. alA'rāf [7]: 31 dan Qs. al-Isrā [17]: 27).

Berbagai deskripsi ayat di atas menegaskan dan menuntut sebuah etika moral dalam pengelolaan dan pemeliharaan alam ini. Manusia dituntut untuk melestarikan alam dan hidup harmonis bersama dengan berbagai spesies yang hidup di dalam alam tersebut. Dalam hal ini tradisi agama menghadirkan suatu hierarki tanggung jawab manusia sebagai mahluk suci dan menjaganya sekaligus untuk tujuan kesehatan jasmaniah ${ }^{71}$. Manusia tidak akan mampu dengan sempurna melaksanakan atau mengemban amānah Allah di atas, kecuali dengan mengembangkan tatanan kepedulian melalui ruang dan waktu mencakup semua spesies, individu dan genarasi mahluk Allah di alam semesta ini.

\section{Akkhirah: sebuah model akuntabilitas dan konsekuensi}

Prinsip lainnya yang terkait dengan lingkungan adalah konsep Islam tentang akhirat atau hal-hal yang berhubungan dengan eskatologi, seperti mizàn, șirät, hisāb, yaumul jazāa, surga, dan neraka. Bagi orang yang beriman, mereka meyakini bahwa setelah kehidupan di dunia ini, akan ada kehidupan selanjunya,

${ }^{70}$ Sardar, Islamic, 228.

${ }^{71}$ Nasr, The Heart, 278. 
yaitu kehidupan di akhirat (hereafter). Kehidupan di akhirat merupakan konsekuensi kehidupan di dunia.

Akhirat adalah waktu dan tempat dimana manusia harus mempertanggungjawabkan segala perbuatan yang pernah ia lakukan selama hidupnya di dunia ini. Baik yang bersifat vertikal dalam hubungannnya dengan Tuhan, maupun yang bersifat horizontal dalam tugas-tugasnya sebagai khalifah yang mengemban amānah untuk berinteraksi sesama manusia, maupun dalam interaksinya dengan makhluk Tuhan yang lainnya, seperti tumbuhan, hewan dan alam sekitar.

Murata dan Chittick menjelaskan bahwa akhirat sesungguhnya merupakan konsep dasar yang menjadi basis bagi segala tingkah laku dan praktik keislaman di dunia ini. Tanpa konsep ini, maka tidak akan mungkin memahami konsep ketuhanan dan konsep kenabian dengan sempurna. ${ }^{72}$ Keyakinan pada adanya hari pembalasan menimbulkan konsep bahwa segala perbuatan di dunia ini mempunyai konsekuensi di akhirat.

Pada hari akhirat inilah akan terbukti bahwa amānah yang diterima manusia dapat menjadi sumber kehinaan, apabila manusia tidak mampu mengemban dan melaksanakan tugas kosmisnya sebagai khalifah, namun ia juga dapat menjadi sumber keagungan bagi manusia apabila ia mampu mengembannya.

Konsep ini dapat menjadi dasar bagi lahirnya etika lingkungan yang bersifat holistik dan integral. Adanya konskuensi dalam setiap perbuatan manusia membuat manusia harus bersikap berhati-hati dan mempersiapkan apa yang akan ia bawa pada kehidupan di akhirat nanti. Konsep ini juga dapat menjadi bingkai dan sekaligus rambu-rambu peringatan dalam kerangka pemanfaatan dan pengelolaan alam. Manusia dilarang untuk mengekspolitasi alam dengan nafsu serakahnya dan perilaku konsumsi yang melampui batas. Bahkan konsep ini bisa menjadi petunjuk dan orientasi seorang muslim dalam hidupnya, sehingga manusia tidak akan berbuat kerusakan di dunia ini. Manusia tidak dapat berbuat yang bersifat destruktif dan

${ }^{72}$ Murata dan Chittick, The Vision, 265. 
dominasi terhadap alam karena semuanya ada tanggungjawab dan akuntabilitasnya di hadapan Allah.

\section{Catatan Akhir}

Ada dua agenda profetis perenial Islam yang mendesak untuk dirumuskan terkait dengan krisis lingkungan menurut Nasr. Pertama, memformulasikan dan memperkenalkan sejelasjelasnya, dalam bahasa kontemporer, hikmah perenial (philosophia perennis) Islam tentang tatanan alam, signifikansi religiusnya, dan kaitan eratnya dengan setiap fase kehidupan. Kedua, menumbuhkembangkan kesadaran ekologis yang berperspektif teologis (eco-theology), dan jika perlu, memperluas wilayah aplikasinya sejalan dengan prinsip syari’ah (agama) itu sendiri.

Ecoteology Islam yang bersumber dari ecotheology dan kosmologi sakral dapat berkontribusi positif sebagai guiding principles pengelolaan alam. Kontribusi tersebut nampak jelas pada beberapa prinsip ecotheologi Islam yaitu: prinsip taubid (unity of all creation), prinsip amanah-khalifah (trustworthiness-moral leadership), dan äkhirah (responsibility).

Prinsip tawhid (unity in diversity) mengharuskan muslim melihat bahwa alam bukanlah entitas-entitas yang tidak mempunyai nilai sakral. Muslim harus meyakini bahwa alam dan segala makhluk yang menghuninya merupakan satu-kesatuan baik dari segi asal maupun tujuan. Alam ini bukanlah milik manusia, kepemilikan manusia tersebut hanyalah bersifat amānah, titipan yang suatu saat harus dipertanggungjawabkan kepada pemilik-Nya. Sebagai pengemban amānah seharusnya manusia tidak bertindak eksploitatif dan merusak alam yang akan menyebabkan manusia menerima murka Allah dan tergolong sebagai orang aălim. Adanya konskuensi dalam setiap perbuatan manusia mengharuskan manusia berhati-hati dan mempersiapkan bekal yang ia bawa pada kehidupan di akhirat kelak. Konsep äkhirah (responsibility) dapat menjadi bingkai dan sekaligus rambu-rambu peringatan dalam kerangka pemanfaatan dan pengelolaan alam. $W$ a al-Lāh a lam bi al-sawäb. 


\section{Daftar Pustaka}

Ali, Abdullah Yusuf. 1989. The Holy Qur'an; Text, Translation and Commentary. Maryland: Amana Corporation.

Bakar, Osman. 1998. Taubid and Science; Islamic Perspectives on Religion and Science. Cambridge: The Islamic Text Society.

Capra, Frithjof. 1996. The Web of Life. London: Harper Collins. al-Faruqi, Ismail Raji. 1992. Al Tawhid: Its Implications for Thought and Life. Virginia, USA: International Institute of Islamic Thought.

Foley, Gerald. 1993. Pemanasan Global; Siapakah yang Merasakan Panas?. Jakarta: Yayasan Obor Indonesia.

Foltz, Richard. 2003. Islam and Ecology; A Bestowed Trust. USA: The President and Fellows of Harvard College.

Gore, Albert Jr. 1992. Earth in the Balance: Ecology and the Human Spirit. New York: Houghton Mifflin.

Griffin, Daid Ray. 1989. God and Religion in the Postmodern World; Essays in Post Modern Theology. Albany: state university of New York Press.

Khalid, Fazlun. 2002. "Islam and the Environment" in: Timmerman.

P. (ed) Encyclopedia of Global Environmental Change. Chichester: John Wiley \& Sons Ltd.

Kodra, Hadi S. Ali. 2004. Bumi Makin Panas Banjir Makin Luas; Menyibak Tragedi Hutan. Bandung: Yayasan Nuansa Cendikia.

Maclntyre, Alasdair. 1967. "pantheism' The Encyclopedia of Philosophy. ed. Paul Edwards, vol. 8. New York: The Macmillan Company \& The Free Press.

Miller, G. Tyler. 1972. Reflenish The Earth: A Primer in Human Ecology. Belmnt. Calif: Wadsworth.

Mujiyono. 2005. “Teologi Lingkungan Islam”. Disertasi. Jakarta: UIN Syarif Hidayatullah Jakarta.

Murata, Sachiko. 1992. The Tao of Islam; A Sourcebook on Gender Relationships in Islamic Thoughts. Albany: State Univerity of New York Press.

Narayan, Vasudha. 2000. Water, Wood and Wisdom; Hindu Ecological Perspectives dalam Harold Coward and Daniel McGuire, eds. Vision of The Earth. New York: State University of New York Press. 
Nasr, Seyyed Hossein. 1989. Knowledge and The Sacred. New York; State University of New York Press.

.1976. Man and Nature, The Spiritual Crisis of Modern

Man. London: George Allen \& Unwin.

. 1996. Religion and the Order of Nature. New York:

Oxford Univbersity Press.

. tt. Man in The Universe; The Islamic View. London:

Longman.

Ozdemir, Ibrahim. "Toward an Understanding of Environmental Ethics from Qur'anic Perspective". Researh Seminar "Religion and Ecology". Yogyakarta: August 9-13 2005.

Passmore, John. 1974. Man's Responsibility for Nature: Ecological Problem and Western Tradition. New York: Scribner's.

al-Qardhawi, Yusuf. 2002. Islam Agama Ramah Lingkungan, ter. Jakarta: Pustaka al-Kautsar.

Quṭub, Sayyid. 1971. Tafsìr Fì Zilāl al-Qurā'n, Jilid 7. Beirūt: Ihyāā al-Turāth al-'Arabī.

Sale, Kirkpatrick. tt. The Green Revolution: The American Environmental Movement, 1962-1992. New York: Hill and Wang.

Salim, Emil. 1979. Lingkungan Hidup dan Pembangunan. Jakarta: Mutiara.

Santoso, Y. Eko. 2003. Menuju keselarasan Lingkungan; Pandangan Teologis Terhadap Pencemaran Lingkungan. Malang: Averroes Press

Schumacher, E.F. 1978. A Guide for The Perplexed. New York: Harper Colophon Books.

Soemarwoto, Otto. 2007. Analisis Mengenai Dampak Lingkungan. Yogyakarta: UGM Press.

Toynbee, Arnold. 1974. "The Relegious Background of the Present Environmental Crisis", dalam David and Eileen Spring (ed). Ecology and Religion in History. New York: Harper and Row.

Tucker, Mary Evelyn. 2000. Hinduism and Ecology. Cambrigde:

Harvard University Press.

White, Lynn Jr. 1967. The Historical Roots of Our Ecological Crisis, Science 155, 10 Maret 1967. 
Whitehead, A.N. 1926. Science and The Modern World. New York: Macmillan Company.

Yazdi, Muhammad Taqi Misbah. tt. At-Tawhid or Monotheism, As in the ideological and The value system of Islam. Iran: Islamic Propagation organization. 